Acta vet. scand. $1959,1,1-11$.

From the Institute of Sterility Research, The Royal Veterinary and Agricultural College, Department of Obstetrics and Gynaecology, Copenhagen.

\title{
GENITAL VIBRIOSIS IN THE BOVINE
}

AN EXPERIMENTAL STUDY ON THE INFLUENCE ON EARLY EMBRYONIC MORTALITY

By

H. C. Adler.

It is generally agreed that early embryonic mortality can to some extent be considered "normal" i. e. regarded as the mere result of malformed or at least inferior embryos succumbing, in other words a condition arisen primarily at the moment of fertilization. It is possible that certain animals shed an abnormally great number of germ cells producing inferior zygotes, and under certain circumstances (inbreeding) the incidence of early embryonic death caused genetically can undoubtedly increase to such an extent that it must be considered definitely pathologic.

Another category of embryonic death is provoked by subnormal uterine conditions inhibiting the development of a zygote which is normal from the outset. Such abnormal conditions may possibly be the result of hormonal disturbancy (in certain cases caused by malnutrition), or infection, or both.

Several investigators have reported cases of an abnormally high incidence of embryonic death in the bovine. However, in most cases they present little or no aetiological evidence; Laing (1945, 1949 and 1952), Tanabe and Casida (1949), Casida (1950), Stewart (1952), Hawk et al. (1955) and Wiltbank et al. (1956). The evidence of early embryonic death occurring in cattle arises partly from experimentation, and partly from studies of A.I. records.

Several investigations have established that Vibrio fetus, when introduced into the genital tract of the female bovine, 
causes a temporary infertility without giving rise to distinct clinical symptoms, the "featureless" repeated return to heat being the only sign of a pathologic condition. However, little is known exactly about the pathogenesis; i.e. the way in which the reproductive functions are disturbed. Is the fertilization prevented, or does fertilization take place and early embryonic death then occur?

Stegenga (1950) reported that prolonged breeding intervals were observed relatively frequently in Vibrio fetus infected cows. Adler (1953) demonstrated that with artificial insemination with semen from Vibrio fetus infected bulls the subsequent breeding intervals of the repeat breeders were prolonged more frequently than was normal. It was also found that, at the second insemination, a decreased fertility rate could be demonstrated to an equal extent in the cows returning to heat after a normal interval and in those returning to heat after a prolonged interval.

However, as far as is known experimental investigations have not hitherto been carried out with a view to demonstrating directly whether the Vibrio fetus infection provokes early embryonic death. This paper is a preliminary report on such investigations.

\section{MATERIAL AND METHOD}

In ten experiments the animals used were heifers 12 to 14 months old (estimated) selected at random from the weekly supply at the abattoir of Copenhagen. The heifers were subjected to rectal palpation and the tampon test, Szabo (1951 a), and only non-pregnants, and non-reactors to Vibrio fetus, were used. Each single experiment used two heifers. In each case oestrus was produced by enucleation of the corpus luteum.

The standard procedure for insemination was as follows: The heifers were inseminated intracervically 74 to 76 hours after enucleation of the corpus luteum, and again at about 90 and 98 hours. In the first two experiments undiluted semen collected from an A.I. bull diagnosed to be Vibrio fetus infected was used. In the remaining experiments was used semen collected from one particular bull belonging to an A.I. centre, the bulls of which were all free from Vibrio fetus infection for the preceding three years as evidenced by regular control by the author's method, Adler (1957). The collected semen was diluted $1: 10$ with homogenized, sterilized cream (9\% fat), Adler and Rasbech (1956), 
without addition of antibiotics. $1 \mathrm{ml}$. of this semen was inseminated. Less than five minutes later $0.2 \mathrm{ml}$. of a recently isolated strain of Vibrio fetus, cultured for three days in a semisolid medium, Szabo (1951 b), was introduced into the posterior part of the cervical canal. During the experimental period the bull in question was used for 1530 first-inseminations yielding a $60-90$ day non-return percentage of 69.3 , the semen being extended with the above-mentioned diluent. The Vibrio fetus cultures (a new isolate for every single experiment) were selected at random among the cultures isolated from heifers used for test-mating of bulls, Adler (1957).

As a rule one of the two heifers (later in this article mentioned as heifer I), was slaughtered 18 days after the enucleation of the corpus luteum, i. e. $14-15$ days after insemination and 15 days after inoculation. The genital organs were removed. The uterine horn, which (from the seat of the corpus luteum) could be anticipated to be pregnant, was isolated, and flushed with $16 \mathrm{ml}$. of physiological saline introduced into the apical part with a syringe and a hypodermic needle and allowed to flow out from the basal part of the horn through an incision and into a Petri-dish.

After that a semi-solid medium was inoculated with material from the uterus as described elsewhere, Adler (1957), in order to isolate vibrios.

The second heifer of each experiment (later mentioned as heifer II) was from the 14th day after inoculation submitted to daily visual and rectal control in order to detect possible signs of heat and regression of the corpus luteum. In case of heat occurring, 7-12 or 27 days were allowed to pass before the corpus luteum was enucleated, and the heifer was again inseminated following the same procedure as for the first series of inseminations, and using semen from the same bull. About 14 days later the heifer was slaughtered and the genital organs removed and examined in the same way as for heifer No. I.

\section{RESULTS}

Data for the ten experiments are shown in Table 1. It will be seen that in nine cases the infection was demonstrated in heifer No. I. In eight of these cases an approximately 14 days old embryo was recovered, five embryos being apparently normal, the remaining three and the embryo from heifer No. 12 being more 


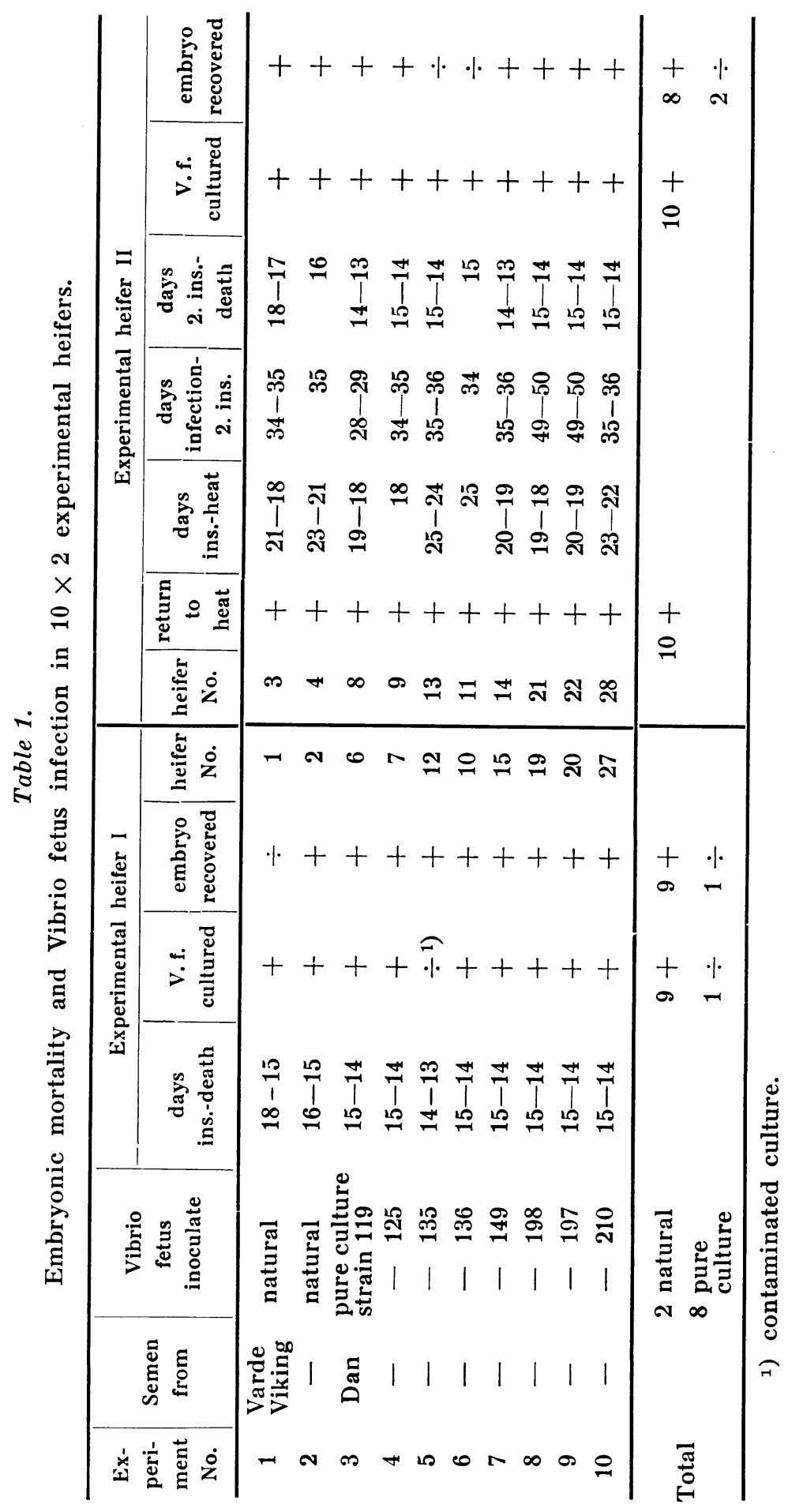


or less degenerated. In all ten experiments heifer No. II returned to heat, in seven cases with an approximately normal oestrus interval, in three cases with an interval a few days longer than normal. The infection was demonstrated in all the No. II heifers after slaughtering, and as a result of reinsemination four to seven weeks after infection an approximately 14 days old embryo was recovered in eight cases, the embryo being apparently normal in three of them and more or less degenerated in five. In the

Table 2.

Localization of the Vibrio fetus infection in the uterus of 19 heifers.

\begin{tabular}{|c|c|c|c|c|c|c|c|c|c|}
\hline \multirow{3}{*}{ No. } & \multirow{3}{*}{\multicolumn{2}{|c|}{ Inoculate }} & \multirow{3}{*}{$\begin{array}{c}\text { Days } \\
\text { after } \\
\text { infection }\end{array}$} & \multicolumn{6}{|c|}{ Vibrio fetus recovered from } \\
\hline & & & & \multicolumn{2}{|c|}{ cervical canal } & \multicolumn{2}{|c|}{ base of horns } & \multicolumn{2}{|c|}{$\begin{array}{l}\text { apical parts } \\
\text { of horns }\end{array}$} \\
\hline & & & & $\begin{array}{c}\text { posterior } \\
\text { part }\end{array}$ & $\begin{array}{c}\text { anterior } \\
\text { part }\end{array}$ & right & left & right & left \\
\hline 1 & \multicolumn{2}{|c|}{$\begin{array}{l}\text { semen from } \\
\text { Varde Viking }\end{array}$} & 18 & + & + & $(-)$ & - & $(-)$ & - \\
\hline 2 & \multicolumn{2}{|c|}{-} & 16 & + & + & - & $(+)$ & + & $(-)$ \\
\hline 3 & \multicolumn{2}{|c|}{-} & 52 & + & + & $(+)$ & + & $(--)$ & - \\
\hline 4 & \multicolumn{2}{|c|}{ - } & 51 & + & + & + & $(+)$ & - & $(-)$ \\
\hline 6 & \multicolumn{2}{|c|}{$\begin{array}{l}\text { pure culture } \\
\text { strain } 119\end{array}$} & 15 & + & + & $(+)$ & + & $(-)$ & - \\
\hline 8 & - & - & 42 & + & + & + & $(+)$ & - & $(-)$ \\
\hline 7 & - & 125 & 15 & + & + & - & $(-)$ & - & $(-)$ \\
\hline 9 & - & - & 49 & + & + & + & $(-)$ & - & $(-)$ \\
\hline 13 & - & 135 & 50 & + & + & + & $(-)$ & - & $(-)$ \\
\hline 10 & - & 136 & 15 & + & + & $(+)$ & + & $(-)$ & + \\
\hline 11 & -- & - & 49 & + & + & $(+)$ & + & $(-)$ & + \\
\hline 15 & - & 149 & 15 & + & + & - & $(+)$ & - & $(-)$ \\
\hline 14 & - & - & 49 & + & + & - & $(-)$ & - & $(-)$ \\
\hline 19 & - & 198 & 15 & + & + & $(+)$ & + & $(-)$ & - \\
\hline 21 & - & - & 64 & + & + & - & $(-)$ & - & $(-)$ \\
\hline 20 & - & 197 & 15 & + & + & + & $(+)$ & + & $(+)$ \\
\hline 22 & - & - & 64 & + & + & $(+)$ & + & $(+)$ & + \\
\hline 27 & - & 210 & 15 & - & + & - & $(-)$ & - & $(-)$ \\
\hline 28 & - & - & 50 & $-1)$ & + & - & $(-)$ & - & $(-)$ \\
\hline Total & & & & $\begin{array}{r}17+ \\
1- \\
11)\end{array}$ & $19+$ & $\begin{array}{l}5 \dashv \\
6(+) \\
7- \\
1(-)\end{array}$ & $\begin{array}{l}6+ \\
5(+) \\
1- \\
7(-)\end{array}$ & $\begin{array}{c}2+ \\
1(+) \\
10- \\
6(-)\end{array}$ & $\begin{array}{c}3+ \\
1(+) \\
4- \\
11(-)\end{array}$ \\
\hline
\end{tabular}

1): Contaminated culture. -() : The horn in question flushed for recovery of embryo. 
remaining two cases embryonic tissue was not found with certainty.

Consequently, in seven of the experiments the Vibrio fetus infection was established in both experimental heifers, an embryo was found two weeks after the infective insemination in heifer No. I, heifer No. II returned to heat, and an embryo was recovered two weeks after a reinsemination.

In Table 2 are given the results of culturing the various parts of the uterus including the cervix from a total of 19 experimental heifers, in which the infection was demonstrated, and it will be seen that Vibrio fetus was recovered in 17 cases from the posterior part of the cervical canal, in 19 cases from the anterior part, in 13 cases from the basal part of at least one horn and in five cases from the apical part of at least one horn. If the flushing of one horn is considered to make the results of cultivating from the horn in question invalid, the result will be that 11 out of 19 intact horn bases and five out of 19 apical horn parts yielded Vibrio fetus.

\section{DISCUSSION}

From the above mentioned experimental results it seems to be an established fact that an infection with Vibrio fetus does not in general interfere with the fertilization, since 17 out of 20 experimental heifers were found fertilized in spite of the fact that 19 of them were shown to be infected and the remaining one most likely infected too, nine being fertilized by insemination at the time of infection and eight by insemination four to seven weeks after the infection took place, the mentioned periods being valid only, if it can be left out of question that the heifers were spontaneously infected beforehand. This possibility might have been excluded by sampling biopsy-specimens for cultivation before the experiments were commenced. However, this precaution was abandoned for fear of the possibility of producing abnormal and fertility-impairing conditions in the genital organs by the biopsy-sampling, and the question was considered of minor importance due to the experience that less than one per cent of the category of heifers, from which the experimental animals were selected at random, were spontaneously infected. Consequently, it seems evident that Vibrio fetus, whether the infection has been newly transferred or is well established, does not affect the fertilization. 
This fact indirectly supports the generally agreed conception that the fertility-impairing effect of the infection is due to an influence on the developing embryo, and, moreover, do the experiments directly point to the Vibrio fetus infection as a cause of the death of the embryo at the age of two to three weeks. In all ten experiments the No. II heifers returned to heat after about three weeks or a few days more, which means that they were either not fertilized or the possibly fertilized ova were destroyed. There is every probability of the latter alternative in the majority of the cases, as in all cases except one the No. I heifers were found fertilized, which heifers were selected and treated in exactly the same way as the No. II heifers. Furthermore, it was found that eight of the No. II heifers later on were fertilized when treated in exactly the same way as before, indicating that the heifers in question were individuals which under the conditions of the experiment shed ova which were capable of being fertilized and forming embryos.

In all cases the eggs available for the fertilization were shed during an oestrus provoked by enucleation of the corpus luteum, and it might be thought that such eggs might condition a lowered conception rate, and in this experiment be responsible for the early embryonic death. However, Friis Jakobsen and Teige (1956) showed that a normal pregnancy-percentage is to be expected in cows inseminated during heat provoked by squeezing out the corpus luteum. This makes the mentioned possibility improbable.

It might be thought that the returning to heat could be a result of an abnormality of the sperm. This possibility might have been excluded by inseminating a No. III heifer under the same experimental conditions, but without inoculating it with Vibrio fetus, in order to get an experimental group, possibly demonstrating normal continued embryonic development. The fact that in eight cases it was a question of semen from a bull, the ordinary use of which resulted in a 60-90 day non-return percentage of 69 , justified the abandonment of such an experimental control group for economic reasons, the non-return rate indicating that the sperms used in the experiment were capable of producing a normal rate of surviving embryos.

Consequently the fact that in no case out of ten an embryo survived longer than about three weeks can hardly be explained 
without supposing the Vibrio fetus infection to be the cause of embryonic death at least in part of the cases.

The results concerning the localization of the infection in the uterus seem to confirm the author's previous observation, Adler (1957), that the cervical canal can be regarded as the most constant seat of the infection.

The present investigations do not create basis for definite conclusions regarding the interrelationship between the localization of the infection and its injuring effect on the embryo, as the distribution of bacteria found post-mortem is not inevitably the same as at the time of the embryonic death, and, even if this was the case, it cannot be known for certain that the heifers Nos. 14, 21 and 28 had been fertilized, which heifers returned to heat and later on were found infected in the cervical canal only. Nevertheless, the investigation draws attention to the possibility that the infection can exert its embryo-injuring effect by being present in the cervix only, creating such conditions that the pregnancy is interrupted, without invading the uterine cavity itself. A corresponding effect was obtained by Roy \& Rowson (1955), who by inserting a steel spring in the cervical canal provoked a condition where conception was not prevented, but pregnancy terminated at an early stage. No effect on the morphology of the genital organs was seen. Whether cervical abnormal conditions caused mechanically or possibly by infections can provoke direct alterations in the uterus, which will interrupt the embryonic development or whether the neuro-hormonal regulation-mechanism is interfered with, is so far not known.

\section{CONCLUSIONS}

The investigation in progress indicates so far:

1. The Vibrio fetus infection newly introduced or well-established in female cattle does not prevent fertilization.

2. The infection is capable of disturbing the embryonic development resulting in embryonic death two to three weeks after fertilization.

3. The bacteria are found in the cervical canal in practically all cases. Less constantly in the cornua and in particular infrequently in the apical parts. 
4. The question arises whether the embryo-injuring effect may not depend on the infection being present in the uterine horns, but may also be seen in cases where Vibrio fetus is present in the cervical canal only.

\section{REFERENCES}

Adler, H. C.: Proc. of The XVth International Veterinary Congress, Stockholm 1953, part I vol. 2, 816.

Adler, $H$. C.: Genital Vibriosis in the Bovine. Diss. Copenhagen 1957. Adler, H. C. \& N. O. Rasbech: Nord. Vet.-Med. 1956, 8, 497.

Casida, L. E.: Vlaam. diergeneesk. T. 1950, 19, 273.

Friis Jakobsen, Kj. \& J. Teige: 291. beretning fra fors $\varnothing$ gslaboratoriet. K $\phi$ benhavn 1956.

Hawk, H. W., J. N. Wiltbank, H. E. Kidder \& L. E. Casida: J. Dairy Sci. 1955, 38, 673.

Laing, J. A.: Vet. Rec. 1945, 57, 275.

Laing, J. A.: J. comp. Path. 1949, 59, 97.

Laing, J. A.: Report of The II International Congress of Physiology and Pathology of Animal Reproduction and of Artificial Insemination, Copenhagen 1952, vol. II, 17.

Roy, A. \& L. E. A. Rowson: Vet. Rec. 1955, 67, 177.

Stegenga, Th.: Vibrio fetus en enzoötische steriliteit. Diss. Utrecht 1950.

Stewart, D. L.: Vet. Rec. 1952, 64, 303.

Szabo, L.: Nature, Lond. 1951 a, 168, 171.

Szabo, L.: Nord. Veterinærforening for Seksualfysiologi og Seksualpatologi 1ste kongress, Stockholm $1951 \mathrm{~b}, B 5$.

Tanabe, T. Y. \& L. E. Casida: J. Dairy Sci. 1949, 32, 237.

Wiltbank, J. N., H. W. Hawk, H. E. Kidder, W. G. Black, L. C. Ulberg \& L. E. Casida: J. Dairy Sci. 1956, 39, 456.

\section{SUMMARY}

The literature on early embryonic mortality in cattle is outlined as well as communications on the fertility-decreasing and oestrusinterval-prolonging effect of the Vibrio fetus infection.

Experiments were performed in which 20 heifers in heat were inseminated with semen of known fertilizing capacity, and at the same time inoculated with Vibrio fetus. Part of the heifers were killed two weeks later, recovery of embryos was attempted, and the uterus cultured. Other experimental heifers were left alive and controlled for returning to heat. These heifers were later on inseminated again, killed two weeks later and submitted to the same procedure as the first mentioned heifers. 
All ten heifers allowed to live returned to heat after about three weeks. From both categories of heifers an embryo was recovered in 17 out of 20 cases. Vibrio fetus was recovered from 19 of the 20 experimental heifers, in all cases from the cervical canal, less frequently from the basal region of the uterine horns, and still less frequently from the apical parts of horns.

The results are discussed, and it is concluded that the experiments so far indicate that the Vibrio fetus infection does not prevent fertilization, but provokes early embryonic death occurring two to three weeks after the fertilization. Infection is most constantly found in the cervical canal, and the question arises whether the embryoinjuring effect can be exerted without the infection being present in the uterus itself.

\section{ZUSAMMENFASSUNG}

Genitale Vibriose beim Rind.

Experimentelle Untersuchungen über den Einfluss auf frühzeitigen Embryotod.

Einleitend findet sich eine Uebersicht über frühere Mitteilungen betreffs frühzeitigen Embryotods beim Rind, ferner über die Fertilität herabsetzende Wirkung der Vibrio fetus-Infektion und deren Einfluss auf die Länge der Brunstintervalle.

Eine Reihe gleicher Versuche wurde ausgeführt, in welchen zwei brünstige Färsen mit Samen von bekanntem Befruchtungsvermögen inseminiert wurden. Gleichzeitig wurden die Versuchsfärsen mit Vibrio fetus-Reinkultur infiziert. Die eine von den Färsen jeden Versuchs wurde zirka zwei Wochen später geschlachtet. Der Uterus wurde auf das Vorkommen eines Embryos und von Vibrio fetus mittels Züchtung untersucht. Die andere Färse, die leben blieb, wurde auf neue Brunst kontrolliert. Diese Färse wurde später von neuem besamt, nach Ablauf von zwei Wochen geschlachtet und derselben Untersuchung wie bei der erstgenannten Versuchsfärse unterzogen.

Alle zehn Färsen, die leben gelassen wurden, wurden nach Ablauf von ungefähr drei Wochen brünstig. Nach der Schlachtung der Versuchsfärsen wurde bei 17 derselben ein Embryo nachgewiesen, und Vibrio fetus liess sich von 19 reinzüchten, und zwar in allen Fällen vom Cervikalkanal, weniger häufig vom basalen Teil der Hörner und noch seltener vom apikalen Teil der Hörner.

Diese Resultate werden diskutiert, und es wird die Schlussfolgerung gezogen, dass die Vibrio fetus-Infektion auf Grund dessen, was die Untersuchungen bis auf weiteres darzulegen scheinen, eine $\mathrm{Be}-$ fruchtung zwar nicht verhindert, aber zu einem frühzeitig, nämlich zwei bis drei Wochen nach der Befruchtung eintretenden Tod des Embryos führt. Die Infektion kommt am konstantesten im Cervikalkanal vor, und die Frage drängt sich auf, ob die schädliche Wirkung auf die Entwicklung des Embryos stattfinden kann, ohne dass die Infektion im Uterus selbst Fuss gefasst hat. 


\section{SAMMENDRAG}

Genital vibriose hos kvæget.

Eksperimentelle unders $\phi$ gelser over indflydelsen på tidlig fosterd $\varnothing d$.

Indledningsvis gennemgâs tidligere meddelelser om tidlig fosterd $\varnothing \mathrm{d}$ hos kvæg, endvidere om Vibrio fetus infektionens frugtbarhedsnedsættende virkning og dens indflydelse på brunstintervallernes længde.

Der udf $\varnothing$ rtes en række ens fors $\varnothing$ g, i hvilke to brunstige kvier blev insemineret med sæd, hvis befrugtningsevne var kendt. Samtidig blev fors $\varnothing$ gskvierne smittet med Vibrio fetus renkultur. Den ene af kvierne i hvert fors $\phi g$ blev slagtet ca. to uger senere. Det unders $\phi$ gtes, om et foster var tilstede i uterus, og der blev foretaget dyrkning fra denne, Den anden kvie fik lov at leve og blev kontrolleret for ny brunst. Denne kvie blev senere insemineret igen, slagtet efter to ugers forl $\varnothing \mathbf{b}$ og underkastet den samme unders $\varnothing$ gelse som den f $\varnothing$ rst omtalte fors $\varnothing \mathrm{gs}-$ kvie.

Alle ti kvier, som blev ladt i live, blev brunstige efter omtrent tre ugers forl $\varnothing \mathrm{b}$. Efter fors $\varnothing$ gskviernes slagtning påvistes et foster hos de 17 af dem, og Vibrio fetus kunne dyrkes fra 19, i alle tilfælde fra cervikalkanalen, mindre hyppigt fra den basale del af hornene og endnu sjældnere fra hornenes apikale dele.

Disse resultater bliver diskuteret, og det konkluderes, at undersøgelserne indtil videre synes at vise, at Vibrio fetus infektionen ikke forhindrer befrugtning, men får tidlig fosterdød til at indtræffe to til tre uger efter befrugtningen. Infektionen findes mest konstant $\mathrm{i}$ cervikalkanalen, og det spørgsmål rejser sig, om den skadelige effekt på fosterudviklingen kan udøves, uden at infektionen er til stede $i$ selve uterus. 